\title{
嬩下痛を主訴とした特発性縦隔気腫例
}

\author{
石 津 吉 彦
}

\section{A Case of Spontaneous Mediastinal Emphysema with Pain during Swallowing}

\author{
Yoshihiko Ishizu \\ (Akoh Central Hospital)
}

\begin{abstract}
A 17-year-old girl with spontaneous mediastinal emphysema is reported. She complained of pain during swallowing of sudden onset. Chest and neck X ray films showed air in the mediastinum and cervical subcutaneous layers but fluororadiography revealed no abnormalities. She recovered rapidly without any complication.
\end{abstract}

Key words: spontaneous mediastinal emphysema, pain during swallowing, subcutaneous emphysema

\section{はじめに}

健康人に誘因なくおてる特発性縦隔気腫はま れで，そのほとんどは胸部痛を訴え内科や外科 を受診し，耳鼻咽喉科を受揨することは極めて 少ない，また症状が比較的軽度であると，経過 観察のみにおわり確定診断に有用な胸部X線写 真が撮られず，見過ごされる可能性む考えら れる.

今回，その臨床経過が他の多くの報告例と異 なる喼下痛を主訴として当科を受診した特発性 縦隔気腫の症例を経験したので，文献的考察を 加えて報告する.

\section{症例}

患者 : 17歳, 女子高校生

初診：1988年 6 月 22 日

\section{主訴：矄下痛}

既往歴・家族歴：特記すべきことはない.

現病歴：1988年 6 月 22 日昼過ぎ，授業中に突 然，何の誘因むなく與下痛が出現したため，養
護教諭のすすめですぐに当院循環器科を受診し た. ての時左前頸部に軽度圧痛を認めたが，血 圧 $106 / 70 \mathrm{mmHg}$ ，脈拍80/分，整，呼吸困難や チアノーゼはなく，胸部聴診でも心雑音や異常 呼吸音は認められないため経過観察とされ，増 悪する際は耳鼻咽喉科を受診するようすすめら れた。 その後，学校にあどり授業を受けていた が，䀣下痛および左前頸部痛が次第に増悪する ため，同日夕方当科を受診した.

初曑時現症：身長 $161 \mathrm{~cm}$ ，体重 $55 \mathrm{~kg}$. 鼻腔 咽頭には異常を認めなかった。喉頭鏡検査で両 側声帯に発赤を認めたが可動性は良好であっ た。頸部の触診で甲状軟骨左縁から上部気管軟 骨左縁に沿って強い圧痛と，皮下気腫による著 明な握雪感および揄髪音を認めた。

初䧐時検査所見：血液検査で赤血球 483 万/ $\mathrm{mm}^{3}$, ヘモグロビン $13.3 \mathrm{~g} / \mathrm{dl}$, 白血球 $8300 /$ $\mathrm{mm}^{3}$, 血小板 25.8 万 $/ \mathrm{mm}^{3}$, 白血球分画は単核 球 $2 \%$, リンパ球19\%, 桿状核好中球13\%，2 
核 $62 \% ， 3$ 核 4\%，CRP 陰性であった。頸部 高圧 X線写真正面像で第 1 胸椎から第 3 胸椎左 縁に索状の透亮像を認め，側面像で前頸部の皮 下気腫之頸部食道にガス像を認めた (図 1). 胸 部X線写真では気管左縁に沿って大動脈弓に達 する透亮像を認め (図 2), 側面像でむ気管前縁 に透亮像が認められた。 食道ファイバースコピ 一で，食道入口部直下より食道全体の拡張と， 入口部直下の左後壁の軽度発赤を認めたが, 粘膜は平滑で明らかな穿孔や出血は認めなかっ た。これより特発性縦隔気腫と診断し, 抗生物 質々鎮痛剂を投与し外来経過観察とした。

臨床経過：6 月 23 日嬩下痛は持続していた が，左前頸部痛は軽減し，頸部高圧X線写真で 屯皮下気腫および食道ガス像もやや減少を認め た. またガストログラフィンによる食道透視で も通過良好で食道よりの造影剤の漏出は認めな かった（図 3 ).6月25日左前頸部痛はほぼ消失 し，嚥下痛も軽度になったが大声を出すと軽度

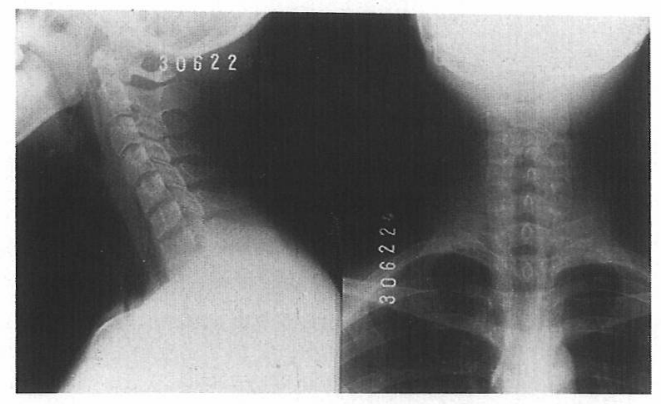

図 1 初影時頸部高圧X線写真

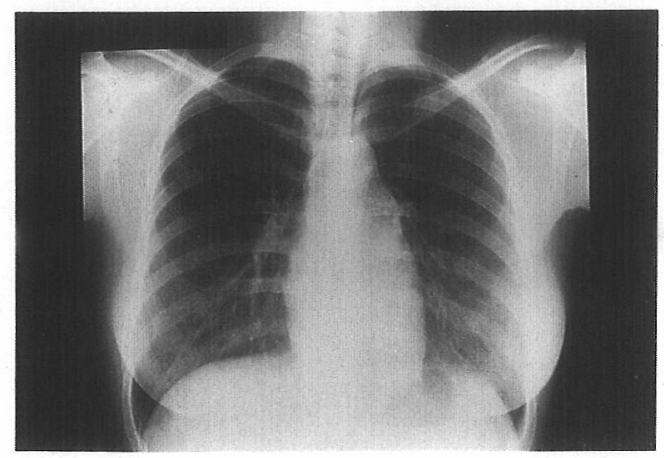

図 2 初晾時胸部X線写真
の前胸部痛があるため，引き続き抗生物質と鎮 痛剂の投与を行った。 6 月 27 日嬹下痛, 左前頸 部痛はなく，皮下気腫も消失し，頸部高圧X線 写真でも正常となった（図 4).

\section{考 察}

1939年 Hamman ${ }^{12}$ は, 初めて特発性縦隔気 腫の概念を記載し，そのなかで “静かに立って いたり，座っていたり，臥床していたとき，す なわち少しの労作も行っていないときに突然発 症するすの”としている。乙のように健康人に なんら誘因なく発症した縱隔気腫を特発性縦隔



図 3 ガストログラフィンによる食道透視

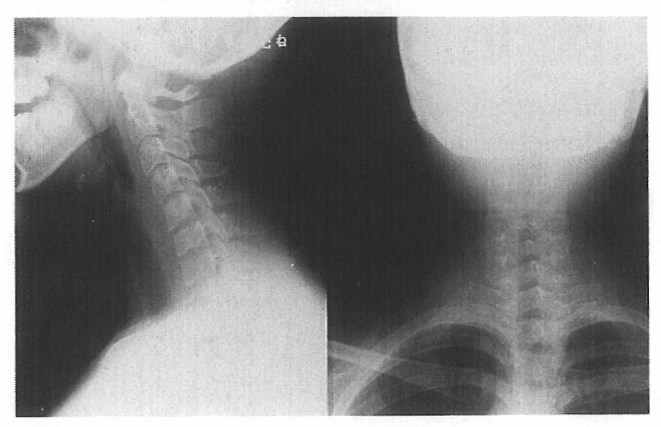

図 4 第 6 病日の頸部高圧X線写真 
気腫といい，Hamman 症候群と屯呼ばれてい る(表 1 )。本邦での報告例をみると，特発性と しながら気管支喘息や感冒などの強い咳嗽発作 後におこったものや，強い怒責などが誘因とな っているものもあり，乙うした症例を除外する と自験例を含めて現在までに 24 例がある（表 2 ). そのなかで年齢，性別の記載のあったも のは14歳から27歳までの21例で，性差は $3 ： 1$ で男性に多く，10代後半から 20 代前半がほとん どであった．主訴のうち最も多いものは胸部痛 で，記載のあった19例のうち13例に認められ， 次いで呼吸困難の 7 例, 胸部圧迫感あるいは異 常感の 4 例の順で，皮下気腫をともなったもの は14例であったままたHamman's sign とよばれ 心拍動と一致して前胸部で聴取される捻髪音が
表 1 縦隔気腫分類 (Engelsing: 19682)

1）特発性縦隔気腫（Hamman 症候群）

2）症候性緹隔気腫（気管支・肺疾患による，気 管支喘息など）

3）新生児における縦隔気腫

4) 続発性縦隔気腫

a ）手術後（甲状腺切除，気管切開術など）

b) 診断ならびに治療のための操作（気腹, 気 縦隔，気後腹膜腔，気管支鏡，気管内麻酔， 人工呼吸など）

c）異物の吸入

5）外傷性縦隔気腫

a）縦隔の直接開放

b）気管・主気管支・食道の穿孔

c) 肉体的過労 (重量物の運搬など)

表 2 特発性縦隔気腫の報告例，自験例




特徵的な所見とされているが，乙の有無につい ての記載のあった12例のうち8 例に認められて いる(表 2 ). これは心拍動にともなって縦隔 内に眝留した空気により発生するといわれてい るが，本症例では確認されなかった。その理由 として本症例での気腫の部位が，X線写真から もわかるように上縦隔であったためと考えられ る。また突然抢こる前胸部痛之呼吸困難あるい は胸部圧迫感という自覚症状より, 本症の患者 は心管系の疾患を考えて内科あるいは外科を受 診するものと思われ，本症例のように䁵下痛を 主訴とし, 耳鼻咽喉科で特発性緃隔気腫之診断 されたものは自験例以外報告はない，治癒まで の平均日数は，記載のあった16例より求めると 8.5 日之比較的短期間であり，その治療も全例 で保存的なあのだけで，予後は良好であった。 乙れは患者に, 基礎疾患がないためと思われる.

つぎに箕輪3 ${ }^{3}$ の体重増減率算出図から, 身長 および体重の記載のあった11例について体重増 減率を求めると正常範囲 6 例, やせすぎ I 度 4 例，やせすぎ血度 1 例と約半数がやせすぎであ った。 乙うした体格的特徵や若年男性に多いて とが本邦に抢ける自然気胸のそれとよく似てい る ${ }^{4}$. また胸膜直下のブレブの破裂が自然気胸 の発症機転と考えられていることより，特発性 縱隔気腫は肺血管鞘近くにできたブレブの破裂 により発症するといわれているが5)6)，本症の X線写真や CT でブレブが証明されたという報 告はなく，またその再発の報告もないことよ り，その発症には自然気胸と異なる因子が関与 しているものと考えられる.

\section{結語}

健康人に誘因なく発症した特発性縦隔気腫の 1 例を経験したので文献的考察を加えて報告し た。本症は突然の胸部痛や呼吸困難とともに皮 下気腫をおこし，聴診で Hamman's sign とい われる胸部雑音を認めるが，保存的治療のみで 比較的短期間に治癒し，予後良好な疾患であ る。またその診断には頸部および胸部のX線写 真が有用である。
本論文の要旨は，第14回日耳鼻中国四国連合地方部 会で口演した.

\section{文献}

1) Hamman L:Spontaneous Mediastinal Emphysema. Bull Johns Hopkins Hosp $64: 1 \sim$ 21, 1939.

2) Engelsing B:Das spontane Mediastinalemphysem. Munch Med Wochenschr 110:1400 $\sim 1403,1968$.

3 ）箕輪真一: 肥満の判定. 公衆衛生 $46: 520 \sim 527$, 1982.

4) 堀越裕一, 花島恒雄, 森田武子, 他 : 健康人に発 症した特発性䋛隔気腫の 5 例一本邦報告例の集計 ならびに本症の個体要因に関する検討. 日胸 42: 476〜482, 1983.

5 ) Varkey B and Kory RC: Mediastinal and subcutaneous emphysema following function tests. Am Rev of Resp Dis 108 : 1393 1396, 1973.

6 ) 荘田恭聖, 松島敏春, 原 宏紀, 他 : 明らかな原 因ならびに誘因なく発症した縦隔気腫の 1 例. 日 胸 $41: 439 \sim 443,1982$.

7 ) 佐藤俊郎, 佐藤 実, 山崎岐男: 特発性縱隔気腫 について. 日胸 $31: 725 \sim 730,1972$.

8 ）西脇隆志, 大畑正昭, 奈良田光男, 他：特発性縦 隔気腫の 4 例. 日胸外会誌 $23: 923,1975$.

9 ) 名越敏秀, 杉山 悟, 中島知徳: 特発性縦隔気腫 の 2 例. 宮崎医会誌 $2: 229 \sim 234,1978$.

10）土居寿孝，金谷久司，池田正春，他：特発性縱隔 気腫の 1 症例. 日内会誌 $67: 880,1979$.

11）早川克己, 尾野徹雄, 深見正伸, 他 : 縱隔気腪症 例の検討. 日本医学放射線学会誌 $38: 102,1978$.

12）井口 㦑: 特発性縱隔膜気胸. 日本医事新報 2922 : 81 82, 1980.

13）広橋玄正：緹隔気腫．日本医事新報 $2954: 79$, 1980.

14）山科秀機, 松浦雄一郎, 田村陸奥夫, 他：特発性 縦隔気腫の 1 治験例. 広島医学 $34: 259 \sim 262$, 1981.

15）戸谷康信, 前田富美雄, 阿地英昭, 他 : 近年経験 した縱隔気腫の 5 例. 日胸疾会誌 $19: 347,1981$.

16）堅田均, 田村猛夏, 白井史朗, 他 : 皮下気腫を 伴った誘因不明の特発性縦隔気腫の 2 症例一本邦 に打ける報告例と文献的考察. 日胸 $40: 950 \sim$ 
957, 1981.

17）黑木秀明, 高田善介, 安藤 操, 他 : 特発性縱隔 気腫の 1 例. 名古屋市立病院紀要 $5: 31 \sim 34$, 1982.

18）斉藤公明, 郡 義隆, 玉田和彦, 他: 特発性緃隔 気腫の 2 例一とくに心音図および超音波所見につ いて. 内科 $49: 543 \sim 548,1982$.

19）伊藤 仁, 掘場通明, 渡辺幸夫, 他: 縦隔, 皮下 気腫の 4 例一胸部 CT 所見を中心として. 日胸 $43: 341 \sim 347,1984$.

20）加藤誠也, 森 裕二, 大島信一, 他：原因の異な
る緹隔気腫の 3 例. 函医誌 $9: 93 \sim 98,1985$.

21）小林 靖, 満岡 渉, 縄田隆浩, 他: 誘因なく健 常者に発症した特発性縱隔気腫の 1 例. 愛媛医学 $5:$ 519 522, 1986.

22）伊藤純子, 山中龍宏, 久保田元 : 特発性縦隔気腫 (Hamman 症候群) の 1例. 小児科診療 $51: 1066$ $\sim 1068,1988$.

(原稿採択 : 平成元年 2 月 17 日 別刷請求先 : 石津吉彦

T678-02 赤穂市惣門町52-6

赤穂中央病院耳鼻咽喉科 